\section{Annual, Off-season Raspberry Production in Warm Season Climates}

\author{
Rebecca L. Darnell ${ }^{1}$, Bryan Brunner ${ }^{2}$, Horacio E. Alvarado ${ }^{1}$, \\ Jeffrey G. Williamson ${ }^{1}$, María Plaza ${ }^{3}$, and Edna Negrón ${ }^{3}$
}

ADDITIONAL INDEX WORDs. floricane, flowering, fruit, primocane, $R$ ubus idaeus

SUMMARY. There is increasing interest in red raspberry (Rubus idaeus) production worldwide due to increased demand for both fresh and processed fruit. Although the United States is the third largest raspberry producer in the world, domestic demand exceeds supply, and the shortage in fresh market raspberries is filled by imported fruit from Canada during July and August, and from Mexico and Chile during November through May. The raspberry harvest season is well defined and the perishability of the fruit limits postharvest storage. Winter production of raspberry in tropical and subtropical climates could extend the harvest season and allow off-season fruit production during periods of high market prices. The objective of the current study was to examine growth and yield of red raspberry cultivars grown in an annual winter production system in Florida and Puerto Rico. Long cane cultivars were purchased from a nursery in the Pacific northwestern U.S. in 2002 ('Heritage' and 'Tulameen'), 2003 ('Tulameen' and 'Willamette'), and 2004 ('Tulameen' and 'Cascade Delight') and planted in raised beds in polyethylene tunnels in December (Florida) or under an open-sided polyethylene structure in January-March (Puerto Rico). In Florida, harvest occurred from $\sim$ mid-March through the end of May, while in Puerto Rico, harvest occurred from the end of March through early June (except in 2002, when canes were planted in March). Yields per cane varied with cultivar, but ranged from $\sim 80$ to $600 \mathrm{~g} /$ cane for 'Tulameen', 170 to $290 \mathrm{~g} /$ cane for 'Heritage', 135 to $350 \mathrm{~g} /$ cane for 'Willamette', and $\sim 470 \mathrm{~g} /$ cane for 'Cascade Delight'. Economic analysis suggests that, at this point, returns on this system would be marginal. However, increasing cane number per unit area and increasing pollination efficiency may increase yields, while planting earlier would increase the return per unit. The key to success may hinge on developing a system where multi-year production is feasible in a warm winter climate.

$\mathrm{W}$ orldwide interest in growing red raspberries is increasing, due to the increased demand for both processed and high quality fresh fruit. The extremely perishable nature and resultant short shelf life of fresh raspberries, combined with the increased demand, has translated into high prices to the producers. Thus, grower interest in producing this crop is increasing.

The principal raspberry growing areas are central and eastern Europe, and the U.S (Food and Agriculture Organization of the United Nations, 2004). Three states-Washington, California, and Oregon-account for most of the U.S. raspberry produc-

\footnotetext{
${ }^{1}$ Horticultural Sciences Department, University of Florida, Gainesville, FL 32611.

${ }^{2}$ Horticulture Department, University of Puerto Rico, Agricultural Experiment Station, Lajas, PR 00667.

${ }^{3}$ Food Science and Technology Program, University of Puerto Rico, Mayaguez PR 00681.

The technical assistance of Antonio Mercado, Anthony Rivera, and Santos Anel is gratefully acknowledged.
}

tion [U.S. Department of Agriculture (USDA), 2004]. Climatically, these areas are characterized by moderate summer temperatures and sufficiently low winter temperatures to satisfy the chilling requirement.

Although the U.S. is the third largest raspberry producer in the world, domestic demand surpasses production. Fresh market raspberry fruit imports into the U.S. have averaged 10,000 to 12,000 tons per year from 2000 to 2002 (USDA, 2003). Most imports are arriving from Canada in July and August, and Mexico and Chile from November through May (USDA, 2003).

Off-season production of raspberries, and/or expansion of production into nontraditional growing regions could potentially increase the supply of domestically grown fruit, particularly in winter and early spring. The use of protected culture has been explored as a means to do this. For example, winter raspberry production in greenhouses in northern latitudes has been investigated and data suggest that raspberries may be well suited to this production system (Pritts et al., 1999). Greenhouse-grown, containerized, summer-bearing cultivars were grown over a 2 -year period. Fruiting occurred from mid-February to mid-April, and average yield was 11 half-pints/plant (equivalent to $\sim 19,000 \mathrm{lb} /$ acre). The authors concluded that the economics appeared to support the feasibility of this type of production system. However, unexpected pollination and pest problems may surface in a greenhouse production system, and the use of greenhouse heating and supplemental lighting add to production costs (Schloemann, 2004). These problems may be overcome if plants are grown in subtropical or tropical areas with mild winters.

Red raspberries have been grown in subtropical areas on an experimental basis using an annual planting system (Knight et al., 1996). This system uses prechilled raspberry plants obtained from northern nurseries, thus eliminating problems associated with insufficient chilling and dormancy release. Knight et al. (1996) field-planted 'Heritage' and 'Autumn Bliss' raspberry in January in southern Florida. Yields averaged $\sim 1460 \mathrm{lb} /$ acre over the season, with $\sim 450 \mathrm{lb} /$ acre produced in March and April. The authors concluded that high yields and high prices for the harvested fruit made this pro-

\begin{tabular}{llll}
\hline $\begin{array}{l}\text { Units } \\
\text { To convert U.S. to SI, } \\
\text { multiply by }\end{array}$ & U.S. unit & SI unit & $\begin{array}{l}\text { To convert SI to U.S., } \\
\text { multiply by }\end{array}$ \\
\hline 0.3048 & $\mathrm{ft}$ & $\mathrm{m}$ & 3.2808 \\
3.7854 & $\mathrm{gal}$ & $\mathrm{L}$ & 0.2642 \\
2.5400 & inch $(\mathrm{es})$ & $\mathrm{cm}$ & 0.3937 \\
1.1209 & lb/acre & $\mathrm{kg} \cdot \mathrm{ha}^{-1}$ & 0.8922 \\
0.0254 & $\mathrm{mil}$ & $\mathrm{mm}$ & 39.3701 \\
28.3495 & $\mathrm{oz}$ & $\mathrm{g}$ & 0.0353 \\
305.1517 & $\mathrm{oz} / \mathrm{ft}^{2}$ & $\mathrm{~g} \cdot \mathrm{m}^{-2}$ & 0.0033 \\
0.4732 & $\mathrm{pt}$ & $\mathrm{L}$ & 2.1134 \\
0.9072 & $\mathrm{ton}(\mathrm{s})$ & $\mathrm{Mg}$ & 1.1023 \\
$\left({ }^{\circ} \mathrm{F}-32\right) \div 1.8$ & ${ }^{\circ} \mathrm{F}$ & ${ }^{\circ} \mathrm{C}$ & $\left(1.8 \times{ }^{\circ} \mathrm{C}\right)+32$ \\
& & &
\end{tabular}


duction system potentially profitable, even with the annual cost of plants.

A winter production system for raspberry in tropical and subtropical climates could extend the harvest season and allow off-season fruit production during periods of high market prices, when production volume in temperate growing regions is low. The objective of the present study was to evaluate growth and yield of raspberry for annual winter production in both a subtropical (Florida) and tropical (Puerto Rico) climate.

\section{Materials and methods}

Florida. 2002 experiment. Dormant bare-root 'Heritage' (fall bearing) and 'Tulameen' (summer bearing) plants were purchased from a nursery in the Pacific northwestern U.S. in Nov. 2001, and chilled in a walk-in cooler $\left(7^{\circ} \mathrm{C}\right)$ for $1224 \mathrm{~h}$. Both cultivars were purchased as dormant long canes (4-5 ft tall), which is critical to the success of this system since flowering and fruiting can occur on these plants in winter. Raspberries were planted on 28 Dec. 2001 inside a polyethylene tunnel in Gainesville, Fla. (lat. $29.68^{\circ} \mathrm{N}$, long. $82.27^{\circ} \mathrm{W}$ ). The tunnel was $88 \mathrm{ft}$ long, $12 \mathrm{ft}$ wide, and $11 \mathrm{ft}$ high, and was covered with 6-mil-thick ultraviolet-resistant polyethylene film. The sides of the tunnel were raised on warm, sunny days to avoid excessively high temperatures inside the tunnel. A two-bed system containing soilless media ( 1 peat: 1 perlite 11 vermiculite, $\mathrm{pH} 5.5$, depth 8 inches) was used. Plants were spaced at 25 or $50 \mathrm{~cm}$ in-row, with between-row spacing of $1.8 \mathrm{~m}$. A drip irrigation system, using polyethylene lines and microtubes, was installed down the row middles. Plants were irrigated at a daily rate of $0.5 \mathrm{gal} /$ plant for $30 \mathrm{~d}$ after planting. The application frequency was reduced to every other day once plants were established. Prior to bloom, as temperatures increased, the polyethylene was completely removed and plants were irrigated as needed. Plants were fertilized weekly with $20 \mathrm{~N}-8.8 \mathrm{P}-16.6 \mathrm{~K}$ water-soluble fertilizer (J.R. Peters, Allentown, Pa. ) at a rate of $0.6 \mathrm{~g} / \mathrm{plant}$ nitrogen $(\mathrm{N})$. A two-wire trellis system ( $2 \mathrm{ft}$ and $5.5 \mathrm{ft}$ above ground level) was built down each row for plant support. New primocanes were removed in early March and again in mid-April, when primocane height averaged 8 to 10 inches. The experiment was a
$2 \times 2$ factorial with seven replications consisting of five plants per plot in a randomized complete-block design. Data were collected from the middle three plants of the five-plant plot.

Bloom and harvest periods, fruit number, and fruit fresh weight were evaluated. Ripe fruit were harvested at 2-d intervals and samples were analyzed for total soluble solids and titratable acidity.

2003 experiment. Dormant bare-root 'Tulameen' and 'Willamette' (both summer bearing) plants were purchased in Nov. 2002 and chilled as described above. Planting in the polyethylene tunnel was done in an 8inch-deep, two-bed system on $18 \mathrm{Dec}$. 2002 , at a spacing of $50 \mathrm{~cm}$ in-row and $1.8 \mathrm{~m}$ between rows. To increase root media aeration and water drainage, the soilless media from the previous year was modified to 60 perlite: 15 peat: 25 pine bark ( $\mathrm{pH} 6.9$ ). Cultural practices were also as described for 2002 , except that three new primocanes per plant were allowed to grow during the flowering/fruiting season. A completely randomized design with single-plant plots and six replications was used. Bloom and harvest periods, and fruit number and weight were determined.

Puerto Rico. 2002 experiment. 'Heritage' and 'Tulameen' raspberry plants were purchased in Nov. 2001 from the Pacific northwestern U.S. nursery for the Puerto Rico planting, and chilled $\left(6^{\circ} \mathrm{C}\right)$ in a walk-in cooler until early Mar. 2002 (2353 h). Raspberry canes were planted in Lajas, P.R. (lat. $18.02^{\circ} \mathrm{N}$, long. $67.05^{\circ} \mathrm{W}$ ), on 12 Mar. 2002 in a polyethylene-covered structure, lacking side walls, in a similar two-bed system with soilless medium ( 1 peat: 1 perlite, $\mathrm{pH} 6.8$, depth 1 $\mathrm{ft}$ ) as described for the Florida 2002 experiment. Plants were spaced at 25 or $50 \mathrm{~cm}$ in-row, with between-row spacing of $1.6 \mathrm{~m}$. A wire trellis system ( $3 \mathrm{ft}$ above ground level) was built down each row for support and drip irrigation was provided as needed. Plants were fertilized every 2 weeks with $20 \mathrm{~N}-8.8 \mathrm{P}-16.6 \mathrm{~K}$ water-soluble fertilizer (Miller Chemical and Fertilizer Corp., Hanover, Pa.) at a rate of $0.9 \mathrm{~g} /$ plant N. During the experiment, all new primocanes were removed at soil level. The experiment was a $2 \times 2$ factorial (cultivar $\times$ in-row spacing) and the design was a randomized complete block with seven replications and five- plant plots for each cultivar/spacing treatment. Data were collected from the middle three plants in each plot.

Bloom and harvest periods, fruit number, and fruit weight were determined. Ripe fruit were harvested at 3- to 4-d intervals, and samples were analyzed for total soluble solids and titratable acidity.

2003 experiment. Dormant bare-root 'Tulameen' and 'Willamette' long cane plants were purchased prechilled in Feb. 2003. Planting occurred 4 Feb. 2003, utilizing the same two-bed system, polyethylenecovered structure, and fresh soilless mix as previously described for Puerto Rico. Cultural practices were also as described for 2002. A randomized complete-block design with five-plant plots and 10 replications was used. Harvest and data collection were as described for 2002 .

2004 experiment. Dormant, long cane bare-root 'Tulameen' and 'Cascade Delight' (summer bearing) plants were purchased prechilled in Jan. 2004, and planted on 29 Jan., utilizing the same planting system, experimental design, and cultural practices as described for 2003 . Harvest and data collection were also the same as previously described.

\section{Results}

FLORIDA. 2002 EXPERIMENT. Two variables, cultivar and in-row spacing, were examined in the 2002 experiment. Budbreak began in Feb. 2002 , with flowering occurring earlier for 'Heritage' (9 Feb. 2002, $43 \mathrm{~d}$ after planting) than for 'Tulameen' (17 Feb. 2002, $51 \mathrm{~d}$ after planting). However, days to $50 \%$ bloom were similar $(\sim 80$ $\mathrm{d}$ after planting). Because of the earlier budbreak, the bloom period was significantly longer for 'Heritage' than 'Tulameen' [57.4 vs. $49.2 \mathrm{~d}$, respectively $(P \leq 0.01)]$. There was no difference in flower number per cane between cultivars (Table 1). Floral budbreak began about the same time for both in-row spacings ( $~ 47 \mathrm{~d}$ after planting), but the bloom period was significantly shorter in the $25-\mathrm{cm}$ spacing compared with the $50-\mathrm{cm}$ spacing [ 51.5 vs. 55.5 $\mathrm{d}$, respectively $(P \leq 0.05)]$. There was also a decrease in flower number/cane at the $25-\mathrm{cm}$ spacing compared with the $50-\mathrm{cm}$ spacing (Table 1 ).

The fruit development period (days from $50 \%$ bloom to $50 \%$ fruit ripening) was longer in 'Heritage' 
Table 1. The reproductive development of 'Tulameen' and 'Heritage' raspberries grown at two in-row spacings in an annual winter production system in Florida in $2002(n=7)$.

\begin{tabular}{|c|c|c|c|c|c|c|}
\hline & $\begin{array}{c}\text { Flowers } \\
\text { (no./cane) }\end{array}$ & $\begin{array}{c}\text { Fruit } \\
\text { (no./cane) }\end{array}$ & $\begin{array}{c}\text { Fruit size } \\
(\mathrm{g})^{\mathrm{z}}\end{array}$ & $\begin{array}{c}\text { Yield } \\
\text { (g/cane) }\end{array}$ & $\begin{array}{c}\text { Soluble } \\
\text { solids } \\
(\%)\end{array}$ & $\begin{array}{c}\text { Titratable } \\
\text { acidity } \\
(\%)\end{array}$ \\
\hline \multicolumn{7}{|l|}{ Cultivar } \\
\hline Tulameen & 114.7 & 100.4 & 3.1 & 309.8 & 13.7 & 0.83 \\
\hline Heritage & 105.9 & 97.7 & 1.7 & 169.5 & 13.1 & 1.14 \\
\hline Significance & NS & NS & $P \leq 0.01$ & $P \leq 0.01$ & $P \leq 0.01$ & $P \leq 0.01$ \\
\hline \multicolumn{7}{|c|}{ In-row spacing $(\mathrm{cm})^{\mathrm{y}}$} \\
\hline 25 & 91.2 & 79.6 & 2.4 & 192.0 & 13.1 & 1.02 \\
\hline 50 & 129.4 & 118.5 & 2.4 & 287.3 & 13.7 & 0.96 \\
\hline Significance & $P \leq 0.01$ & $P \leq 0.05$ & NS & $P \leq 0.01$ & $P \leq 0.05$ & NS \\
\hline
\end{tabular}

${ }^{\mathrm{z}} \mathrm{lg}=0.0353 \mathrm{oz}$

${ }^{\mathrm{y}} \mathrm{cm}=0.3937$ inch.

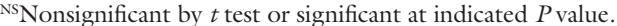

than in 'Tulameen' [34.6 vs. $30.1 \mathrm{~d}$, respectively $(P \leq 0.01)$ ]. However, due to the earlier floral budbreak in 'Heritage', fruit harvest started earlier. Ripe fruit in 'Heritage' were harvested from 14 Mar. through 18 May, while 'Tulameen' fruit harvest began 25 Mar. and continued through 13 May. The major harvest period for both cultivars occurred from 30 Mar. through 24 Apr., when $53 \%$ and $73 \%$ of the total fruit yield was harvested from 'Heritage' and 'Tulameen', respectively. In-row spacing did not affect fruit development period or the fruit harvest period (data not shown).

There was no difference in final fruit number between cultivars, with an average of 100 fruit per cane (Table 1 ). However, fruit fresh weight was nearly twice as great in 'Tulameen' compared with 'Heritage', averaging 3.1 vs. $1.7 \mathrm{~g} /$ fruit, respectively. This translated into significantly higher yields in 'Tulameen' compared with 'Heritage' (Table 1). In addition, 'Heritage' fruit exhibited symptoms of sunburn, where red coloration failed to develop on the sun-exposed portion of the fruit. This appears to be primarily a high ultraviolet light injury, and was not observed on 'Tulameen' fruit. Visual observation indicated there was no difference in canopy development between the two cultivars that might account for differences in sunscald susceptibility between the two cultivars.

In-row spacing significantly influenced flower and fruit number (Table 1). Fruit number averaged 118 fruit/plant at the $50-\mathrm{cm}$ spacing and 80 fruit/plant at the $25-\mathrm{cm}$ spacing. There was no effect of in-row spacing on fruit size, but the increased fruit number at the wider spacing resulted in a significant yield increase per cane compared with the closer spacing (Table 1). On a unit area basis, however, yield was greater at the closer spacing (426.2 and $318.9 \mathrm{~g} \cdot \mathrm{m}^{-2}$ for $25-\mathrm{cm}$ and $50-\mathrm{cm}$ inrow spacing, respectively,). There was no interaction between cultivar and spacing on yield components.

Fruit soluble solids were higher in 'Tulameen' than in 'Heritage', while titratable acidity was lower (Table 1). Plants at $50-\mathrm{cm}$ in-row spacing had increased soluble solids compared with plants at $25-\mathrm{cm}$ spacing, while fruit acidity was not affected. There was no interaction between cultivar and spacing on fruit quality.

FLORIDA. 2003 EXPERIMENT. In 2003, two cultivars ('Tulameen' and 'Willamette') were compared at one in-row spacing $(50 \mathrm{~cm})$. Bloom in 'Willamette' began 11 Feb. 2003 and continued through 14 May, with the peak in late February. Bloom began and ended later in 'Tulameen' (Feb. 17 through May 20), with the peak in early March. Harvest occurred from 17 Mar. through 8 June 2003 for 'Willamette', and 19 Mar. through 15 June for 'Tulameen'. There was no difference in yield components between cultivars, and yields were low for both. Fruit number averaged $\sim 65$ fruit/cane, fruit size averaged $\sim 2.2 \mathrm{~g} /$ fruit, and yield averaged $\sim 145 \mathrm{~g} /$ cane for both cultivars.

Puerto Rico. 2002 eXPeriment. As in the 2002 Florida experiment, this experiment compared two cultivars at two in-row spacings. Floral budbreak began earlier in 'Heritage' than 'Tulameen' [10 Apr. $2002(29$ d after planting) vs. 19 Apr. 2002 (38 $\mathrm{d}$ after planting), respectively ( $P \leq$ $0.001)]$. However, the fruit development period (days from first bloom to first fruit) was longer in 'Heritage' compared with 'Tulameen' [24.6 vs. $18.9 \mathrm{~d}$, respectively $(P \leq 0.01)]$; thus, the harvest period was similar for both cultivars. Ripe fruit of both cultivars were harvested from $~ 6$ May through 6 July. Floral budbreak was earlier at the $50-\mathrm{cm}$ spacing compared with the 25 $\mathrm{cm}$ spacing (32 vs. $35 \mathrm{~d}$, respectively), but the difference was nonsignificant. However, this could explain why decreasing in-row spacing from 50 to 25 $\mathrm{cm}$ decreased harvest period [63 vs. $58 \mathrm{~d}$, respectively $(P \leq 0.05)]$. In-row spacing had no significant effect on fruit development period.

Similar to the 2002 Florida results, there was no cultivar effect on fruit number/cane; however, 'Tulameen' fruit weight was significantly greater than 'Heritage', resulting in greater yield/cane in 'Tulameen' (Table 2).

Table 2. The reproductive development of 'Tulameen' and 'Heritage' raspberries grown at two in-row spacings in an annual winter production system in Puerto Rico in $2002(\mathbf{n}=7)$.

\begin{tabular}{|c|c|c|c|c|c|}
\hline & $\begin{array}{c}\text { Fruit } \\
\text { (no./cane) }\end{array}$ & $\begin{array}{c}\text { Fruit size } \\
(\mathrm{g})^{\mathrm{z}}\end{array}$ & $\begin{array}{c}\text { Yield } \\
\text { (g/cane) }\end{array}$ & $\begin{array}{c}\text { Soluble } \\
\text { solids } \\
(\%)\end{array}$ & $\begin{array}{c}\text { Titratable } \\
\text { acidity } \\
(\%)\end{array}$ \\
\hline \multicolumn{6}{|l|}{ Cultivar } \\
\hline Tulameen & 152.4 & 2.3 & 343.6 & 11.4 & 1.9 \\
\hline Heritage & 176.0 & 1.6 & 287.1 & 9.8 & 2.5 \\
\hline Significance & NS & $P \leq 0.001$ & $P \leq 0.10$ & $P \leq 0.001$ & $P \leq 0.001$ \\
\hline \multicolumn{6}{|c|}{ In-row spacing $(\mathrm{cm})^{y}$} \\
\hline 25 & 153.7 & 1.9 & 288.0 & 10.4 & 2.0 \\
\hline 50 & 174.3 & 2.0 & 342.7 & 10.8 & 2.2 \\
\hline Significance & NS & NS & NS & NS & NS \\
\hline
\end{tabular}


However, unlike the Florida planting, in-row spacing had no effect on fruit number or yield per cane.

Fruit quality differences between cultivars in Puerto Rico were similar to results observed in Florida. Soluble solids were higher and titratable acidity was lower for 'Tulameen' compared with 'Heritage' fruit (Table 2). However, there were no effects of in-row spacing on fruit quality, nor were there significant interactions between cultivar and spacing.

Puerto Rico. 2003 experiMENT. In this experiment, two cultivars ('Tulameen' and 'Willamette') were compared at one in-row spacing ( 50 $\mathrm{cm})$. There was no difference in timing of floral budbreak between cultivars; budbreak began 10 Mar. in both cultivars (33 d after planting). The fruit development period was also similar between cultivars, averaging $22 \mathrm{~d}$. Fruit harvest in both cultivars occurred from l Apr. through 31 May.

'Tulameen' produced significantly more fruit/cane than did 'Willamette' (Table 3). 'Tulameen' fruit were also larger, and both these factors resulted in significantly greater yields for 'Tulameen' ( $600 \mathrm{~g} /$ cane) compared with 'Willamette' ( $350 \mathrm{~g} /$ cane $)$. Fruit soluble solids were also greater for 'Tulameen' compared with 'Willamette' (Table 3).

Puerto Rico. 2004 experiMENT. The 2004 experiment again examined the performance of 'Tulameen'; however, 'Willamette' was replaced by 'Cascade Delight'. Only one in-row spacing $(50 \mathrm{~cm})$ was used. There was no meaningful difference in the beginning of floral budbreak between 'Tulameen' (20 Mar., $51 \mathrm{~d}$ after planting) and 'Cascade Delight' (16 Mar., $47 \mathrm{~d}$ after planting). The fruit development period was similar between cultivars, averaging $22 \mathrm{~d}$. The harvest period; however, was shorter in 'Tulameem' (33 d) than 'Cascade Delight' ( $43 \mathrm{~d})$. This may have been due to slightly higher temperatures at the beginning of fruit ripening in 'Tulameen' and faster accumulation of growing degree units. 'Tulameen' fruit ripened from 14 Apr. through 17 May, when mean daily temperatures averaged $24.9{ }^{\circ} \mathrm{C}$. Fruit of 'Cascade Delight' ripened from 2 Apr. through 15 May, when mean daily temperatures averaged $25.9^{\circ} \mathrm{C}$.

Fruit weight of 'Cascade Delight' was significantly greater than fruit

Table 3. The reproductive development of raspberry cultivars grown in an annual winter production system in Puerto Rico in 2003 and 2004 at in-row spacing of $50 \mathrm{~cm}(19.7$ inches $)(\mathrm{n}=10)$.

\begin{tabular}{|c|c|c|c|c|c|}
\hline & $\begin{array}{c}\text { Fruit } \\
\text { (no./cane) }\end{array}$ & $\begin{array}{c}\text { Fruit size } \\
(\mathrm{g})^{\mathrm{z}}\end{array}$ & $\begin{array}{c}\text { Yield } \\
\text { (g/cane) }\end{array}$ & $\begin{array}{c}\text { Soluble } \\
\text { solids } \\
(\%)\end{array}$ & $\begin{array}{c}\text { Titratable } \\
\text { acidity } \\
(\%)\end{array}$ \\
\hline & & 2003 & & & \\
\hline \multicolumn{6}{|l|}{ Cultivar } \\
\hline Tulameen & 206.9 & 2.9 & 595.6 & 11.4 & 2.1 \\
\hline Willamette & 141.4 & 2.5 & 355.2 & 9.7 & 2.0 \\
\hline Significance & $P \leq 0.05$ & $P \leq 0.001$ & $P \leq 0.01$ & $P \leq 0.01$ & NS \\
\hline & & 2004 & & & \\
\hline \multicolumn{6}{|l|}{ Cultivar } \\
\hline Tulameen & 128.8 & 2.2 & 286.2 & 11.0 & 2.0 \\
\hline Cascade Delight & 143.2 & 3.3 & 468.8 & 9.2 & 1.9 \\
\hline Significance & NS & $P \leq 0.001$ & $P \leq 0.01$ & $P \leq 0.001$ & $P \leq 0.05$ \\
\hline
\end{tabular}

weight of 'Tulameen', averaging 3.3 vs. $2.2 \mathrm{~g}$ /fruit, respectively (Table $3)$. This resulted in a greater yield in 'Cascade Delight'. Fruit soluble solids and titratable acidity were greater in 'Tulameen' compared with 'Cascade Delight' (Table 3).

\section{Discussion}

2002. In both the Florida and Puerto Rico plantings, yields compared favorably with raspberry yields in other annual tunnel culture systems (Knight et al., 1996), as well as with the first (Oliveira et al., 1996, 2002) and second (Oliveira et al., 1998, 2004) years of multi-year tunnel and greenhouse systems for both fall- and summer-bearing cultivars. Previously reported yields of long cane 'Tulameen' in greenhouse production systems ranged from $\sim 250 \mathrm{~g} /$ cane (Kempler, $2001)$ to 2 to 4 half-pints/cane (360 to $720 \mathrm{~g} /$ cane) (University of Massachusetts Extension, 2004), while reported 'Heritage' yields are lower, ranging from $\sim 40 \mathrm{~g} /$ cane (Oliveira et al., 1998, 1999) to $\sim 10 \mathrm{oz} / \mathrm{cane}$ $(\sim 300 \mathrm{~g} /$ cane $)$ (Knight et al., 1996). Estimated yields of 'Tulameen' in our system at the $50 \mathrm{~cm} \times 1.8 \mathrm{~m}$ spacing was 2800 and $3100 \mathrm{~kg} \cdot \mathrm{ha}^{-1}$ for Florida and Puerto Rico, respectively. Estimated 'Heritage' yields were lower, averaging 1500 (Florida) and 2600 $\mathrm{kg} \cdot \mathrm{ha}^{-1}$ (Puerto Rico). Knight et al. (1996) estimated yields of $3220 \mathrm{lb} /$ acre for 'Heritage' planted 9 inches $\times 9$ $\mathrm{ft}$, but this was based on both a spring and fall crop. Yields from field trials in Michigan averaged $3860 \mathrm{lb} /$ acre for 'Heritage' and $1860 \mathrm{lb} /$ acre for
'Tulameen' (Hanson and Morales, 1997). However, our yields were lower than expected yields in other multiyear commercial systems, as well as in multi-year winter greenhouse production systems (Pritts et al., 1999). This is likely due to root loss when plants were removed from the nursery, which would decrease available carbohydrates to support fruit production in the first year (Alvarado et al., 2005).

The lower yield observed in our first year may also be due to a decrease in fruit size. Average fruit size in both cultivars at both locations were $15 \%$ to $50 \%$ smaller than average fruit sizes reported for the same cultivars under traditional systems (Daubeny and Anderson, 1991; Myers, 1993). This may have resulted in the higher fruit soluble solids content in both cultivars than previously reported values (Daubeny and Anderson, 1991; Perkins-Veazie et al., 1993), especially in the Florida planting.

Floral budbreak occurred earlier and fruit development periods were shorter in Puerto Rico compared with Florida. This was likely due to the later planting date in Puerto Rico and the subsequent higher ambient temperatures, which would increase the rate of growing degree day accumulation. The mean daily temperature in Florida from planting until floral budbreak averaged $12.7^{\circ} \mathrm{C}$, while the mean daily temperature in Puerto Rico-where planting did not occur until March and floral budbreak did not occur until mid-April—averaged $24.5^{\circ} \mathrm{C}$.

Although in-row spacing had no effect on reproductive development 
of either cultivar in Puerto Rico, fruit number and therefore cane yield increased as in-row spacing increased from 25 to $50 \mathrm{~cm}$ in the Florida planting. Myers (1993) found that fruit number per cane in 'Heritage' increased during the first year of planting as in-row spacings increased from 25 to $50 \mathrm{~cm}$. However, fruit weight was not affected, and there was no effect of spacing on overall cane yield. The lack of in-row spacing effects on fruit weight in our study suggests that fertilization and irrigation rates at the $25-\mathrm{cm}$ spacing were not limiting to fruit size compared with the $50-\mathrm{cm}$ spacing. Furthermore, there was little effect of in-row spacing on fruit soluble solids in either Florida or Puerto Rico, suggesting that photosynthesis was not limiting to fruit weight at the closer spacing.

2003. Per cane yields of 'Tulameen' in the Puerto Rico planting were higher than reported yields of any raspberry cultivar in an annual tunnel or greenhouse system (Kempler, 2001; Oliveira et al., 1999; University of Massachusetts Extension, 2004). Yields of 'Willamette' were also as high or higher than yields in these other systems. Estimated yield of 'Tulameen' in Puerto Rico was $\sim 5320 \mathrm{~kg} \cdot \mathrm{ha}^{-1}$, while yield of 'Willamette' was estimated at $3170 \mathrm{~kg} \cdot \mathrm{ha}^{-1}$. The low yields observed in the Florida planting may have been due to the retention of primocanes during flowering and fruiting, as has been shown previously (Fernandez and Pritts, 1996; Freeman et al., 1989). However, additional work in our system indicates that retention of three primocanes per floricane does not affect cane yield in 'Tulameen' compared with primocane removal (Alvarado et al., 2005). Thus, the low yields observed in the 2003 Florida planting were more likely a consequence of cool, rainy weather during bloom, which interfered with pollination, as little natural bee activity was observed in the planting. Mean temperatures in Florida during the 2003 bloom period averaged $7.8^{\circ} \mathrm{C}$, compared with 12.7 ${ }^{\circ} \mathrm{C}$ in 2002.

2004. Yield of 'Cascade Delight' was significantly greater than 'Tulameen', in contrast to reports that productivity of this cultivar is very similar to 'Tulameen' (Washington Red Raspberry Commission, 2002). In our study, this difference appears to be due to a significant decrease in yield of 'Tulameen' in 2004 compared with yields in 2002 and 2003. The reason for this decrease is unclear, as mean temperatures during the flowering/fruiting season were similar for all 3 years, ranging from 25.0 to $27.2^{\circ} \mathrm{C}$ in $2002,25.1$ to $26.0^{\circ} \mathrm{C}$ in 2002 , and 24.0 to $25.9^{\circ} \mathrm{C}$ in 2004 . Furthermore, since soilless media was fresh each year, root pathogen buildup was likely not a problem. We did, however, observe later budbreak ( $5 \mathrm{l}$ d after planting) in 'Tulameen' in 2004 compared with 2003 (34 d after planting) and 2002 (38 d after planting). Total shoot length in 'Tulameen' was also greater at anthesis in $2004(242 \mathrm{~cm})$ compared with total shoot length in $2003(218 \mathrm{~cm})$ or $2002(168 \mathrm{~cm})$, although statistical comparisons were not made among years. However, the decreased yield in 'Tulameen' in 2004 compared with the other years may be related to late budbreak and/or increased vegetative growth. In strawberry (Fragaria xananassa), excess early vegetative growth has been shown to delay and decrease flowering (Tehranifar and Battey, 1997), and a similar response may occur in raspberry.

\section{Conclusions}

Our studies indicate that annual fruiting of raspberries in warm climates is achievable, but the economics of an annual system need to be determined. On a retail basis, consumer cost for raspberries imported from Chile and Mexico during the winter range from $\$ 4.00$ to $\$ 6.00$ per half-pint (Schloemann, 2004). Assuming 170-180 g raspberry fruit per half-pint, 300 to $500 \mathrm{~g}$ of fruit per cane would yield 1.7 to 2.9 half-pints per cane. Based on production cost estimates (Koester and Pritts, 2003; Schloemann, $2004)$, and the annual cost of plants and shipping ( $\$ 1.50$ to $\$ 2.00 /$ plant), this return would not meet the costs. However, increasing cane number per unit area and increasing pollination efficiency by bringing in bumblebee hives (which was not done in the current work) may increase yields, while planting earlier would increase the return per unit due to higher market prices. The key to success may hinge on developing a system where multiyear production is feasible in a warm winter climate. Although multi-year off-season raspberry production has been achieved in mild (not warm) winter climates by freeze-protecting canes in tunnels, plants still require chilling to break dormancy (Oliveira et al., $1996,1998)$. In a warm winter climate, where sufficient chilling is unavailable, a multi-year nondormant production system would need to be developed. This may be achieved through pruning and fertilization techniques that prohibit the development of dormancy and therefore negate the need for chilling. This has been successfully accomplished in blueberry (Reeder et al., 1998), and has reportedly been successful in dormant long cane raspberry in south Florida (R. Rafie, personal communication). Additional research is necessary in order to determine if this approach is feasible.

\section{Literature cited}

Alvarado, H.E., R.L. Darnell, and J.G. Williamson. 2005. Carbon mobilization and yield components in raspberry. HortScience 40:1059. (Abstr.)

Daubeny, H.A. and A. Anderson. 1991. Tulameen red raspberry. HortScience 26:1336-1338.

Fernandez, G.E. and M.P. Pritts. 1996. Carbon supply reduction has a minimal influence on current year's red raspberry (Rubusidaeus L.) fruit production. J.Amer. Soc. Hort. Sci. 121:473-477.

Food and Agriculture Organization of the United Nations. 2004. Agriculture production. Crops primary. 16 June 2005. <http://faostat.fao.org/faostat/form?coll ection $=$ Production. Crops. Primary $\& D$ Dom ain $=$ Production \&servlet $=1 \&$ hasbulk $=0 \& v$ ersion $=$ ext\&language $=\mathrm{EN}>$

Freeman, J.A., G.W. Eaton, T.E. Baumann, H.A. Daubeny, and A. Dale. 1989. Primocane removal enhances yield components of raspberries. J. Amer. Soc. Hort. Sci. 114:6-9.

Hanson, E. and M. Morales. 1997. Raspberry variety testing at MSU. 27 Sept. 2005. <http://webl.msue.msu.edu/vanburen/raspvar.htm>.

Kempler, C. 2001. Greenhouse red raspberry production in the Pacific Northwest. 27 Sept. 2005. <http://smallfarms. wsu.edu/crops/greenhouseRaspberries. html>.

Knight, R.J., J.H. Crane, H.H. Bryan, W. Klassen, B. Schaffer, and C. Balerdi. 1996. The potential of autumn-bearing red raspberries as an annual crop for Florida. Proc. Fla. State Hort. Soc. 109:231-232. 
Koester, K. and M. Pritts. 2003. Greenhouse raspberry production guide. 31 Oct. 2005. <http://www.hort.cornell. edu/extension/commercial/fruit/Berries/ghraspl.pdf>.

Myers, S.C. 1993. Primocane development and early yield of 'Heritage' red raspberry in relation to initial plant in-row spacing. J. Amer. Soc. Hort. Sci. 118:6-11.

Oliveira, P.B., L. Lopes-da-Fonseca, and A.A. Monteiro. 2002. Combining different growing techniques for all year round red raspberry production in Portugal. Acta Hort. 585:545-554.

Oliveira, P.B., C.M. Oliveira, L. Lopesda-Fonseca, and A.A. Monteiro. 1996. Off-season production of primocane-fruiting red raspberry using summer pruning and polyethylene tunnels. HortScience 31:805-807.

Oliveira, P.B., C.M. Oliveira, P.V. Machado, L. Lopes-da-Fonseca, and A.A. Monteiro. 1998. Improving off-season production of primocane-fruiting red raspberry by altering summer-pruning intensity. HortScience 33:31-33.

Oliveira, P.B., C.M. Oliveira, and A.A. Monteiro. 2004. Pruning date and cane density affect primocane development and yield of 'Autumn Bliss' raspberry. HortScience 39:520-524.

Oliveira, P.B., C.M. Oliveira, A.A. Monteiro, and L. Lopes-da-Fonseca. 1999. Summer-pruning intensity affects (sic) on off-season production of primocanefruiting red raspberries. Acta Hort. 505:101-105.

Perkins-Veazie, P., G.R. Nonnecke, and R. Gladon. 1993. Development and ripening of primocane-fruiting 'Heritage' raspberry. Acta Hort. 352:209-211.
Pritts, M.P., R.W. Langhans, T.H. Whitlow, M.J. Kelly, and A. Roberts. 1999. Winter raspberry production in greenhouses. HortTechnology 9:13-15.

Reeder, R.K., T.A. Obreza, and R.L. Darnell. 1998. Establishment of a non-dormant blueberry (Vaccinium corymbosum hybrid) production system in a warm winter climate. J. Hort Sci. 73:665-663.

Schloemann, S. 2004. Greenhouse raspberry production for winter sales. 27 Sept. 2005. <http://www.umass.edu/fruitadvisor/factsheets/greenhouserasp/raspberriesgh.htm >.

Tehranifar, A. and N.H. Battey. 1997. Comparison of the effects of $\mathrm{GA}_{3}$ and chilling on vegetative vigour and fruit set in strawberry. Acta Hort. 439:627-631.

University of Massachusetts Extension. 2004. Guidelines for greenhouse raspberry production. 27 Sept. 2005. <http://www. umass.edu/fruitadvisor/factsheets/Raspguide.pdf>.

U.S. Department of Agriculture. 2003. U.S. Department of Agriculture fruit and tree nut yearbook. 16 June 2005. <http:// www.ers.usda.gov/publications/FTS/Yearbook03/fts2003.pdf>.

U.S. Department of Agriculture. 2004. Noncitrus fruits and nuts 2003 summary. 16 June 2005. <http://usda.mannlib. cornell.edu/reports/nassr/fruit/pnfbb/ncit0704.pdf>.

Washington Red Raspberry Commission. 2002. Washington red raspberries. Histories and varietals. 27 Sept. 2005. <http://www.red-raspberry.org/Raspberry/varietals.pdf>. 